V.V. Bondarenko ${ }^{1}$, Cand. Sc. (Tech.), Assoc. Prof., orcid.org/0000-0003-4019-4017, D. I. Skurikhin ${ }^{1}$, Cand. Sc. (Tech.), orcid.org/0000-0002-3746-5157, R. I. Vizniak ${ }^{1}$, Cand. Sc. (Tech.), Assoc. Prof., orcid.org/0000-0001-6179-4981, V. H. Ravlyuk ${ }^{1}$, Cand. Sc. (Tech.), Assoc. Prof., orcid.org/0000-0003-4818-9482,

V. I. Skurikhin ${ }^{2}$, Cand. Sc. (Tech.), orcid.org/0000-0001-7415-7105
1 - Ukrainian State University of Railway Transport, Kharkiv, Ukraine, e-mail: skurikhin@i.ua

2 - National University of Urban Economy in Kharkiv, Kharkiv, Ukraine

\title{
EXPERIMENTAL STUDY OF THE METHOD AND DEVICE FOR WHEEL-SETS ACOUSTIC MONITORING OF RAILWAY CARS IN MOTION
}

Purpose. Improving the technology of maintenance of wheel-sets of passenger cars using the on-board monitoring system and the acoustic monitoring method.

Methodology. Field studies of the acoustic monitoring method were conducted in accordance with the requirements of the current standards using a professional sound recorder. The initial data were analyzed using the licensed software, acoustic signal envelopes were computed using the Hilbert transform, and the values of the peak factor of the acoustic signal from the interaction of the wheel and the rail in the frequency bands were calculated.

Findings. The methods for detection of damages of wheel-sets in the railways of different countries were analyzed and an alternative approach to monitoring the technical condition of wheel-sets in motion of cars was proposed. Field investigations of the acoustic monitoring method were conducted, the obtained data were processed and analyzed, informative diagnostic signs were defined. The results of the study were used for programming and configuring the acoustic monitoring device for wheel-sets.

Originality. For the first time, the noise emission sources of cars were investigated experimentally during operational movement, the noise sources of the rolling stock were classified, and informative diagnostic signs of a signal for the detection of wheel damage were discovered and calculated using the acoustic monitoring method.

Practical value. A model of the acoustic monitoring device was developed and configured based on experimental studies and subsequent calculations, which allowed reducing the number of sensors per car and improving their operational conditions. Laboratory tests of the developed device were conducted.

Keywords: railway transport, cars, wheel-sets, monitoring of technical condition, acoustic control method, field studies, spectrogram, peak factor

Introduction. Natural wear and accidental damage of wheel-sets substantially limits the fault-free operation of passenger cars, which reduces the economic efficiency of the railway, operational reliability and traffic safety.

In the Ukrainian railways, the most failures of units and equipment of passenger cars on the route are recorded on wheel-sets $(54 \%)$, most common of which are shelled treads (44\%), weld-on deposits (14\%) and wheel flats (14\%) on the rolling surface of the wheels.

Such failures of wheels cannot be completely prevented by structural, technological and operational measures, as they may be caused by accidental unpredictable factors, such as short-term dynamic unloading of wheel-sets passing roughness of rails, reduction of the coefficient of adhesion between wheels and rails during atmospheric precipitation, mutual influence of wheel damages, etc. In this case, the task of operative detection of damages to the wheel pair and timely warning of the train crew and ground services of the incident to prevent the threat to traffic safety, minimizing possible losses and shortening the train maintenance time is relevant.

We believe that wheel flats and weld-on deposits on wheelsets of passenger train cars on the route should be promptly detected, since when they are rolled up they form uneven rolling which is especially dangerous at high speeds (120$160 \mathrm{~km} / \mathrm{h}$ ) and difficult to detect in operation. In places of rolled up wheel flats and weld-on deposits, the steel in the rims of the wheels also flakes, which, in further operation, leads to the occurrence of cracks and the destruction of the wheel.

Literature review. Approaches to data acquisition in the railway transport can be divided into four groups: infrastruc-

(C) Bondarenko V.V., Skurikhin D. I., Vizniak R. I., Ravlyuk V.H., Skurikhin V. I., 2019 ture monitoring using ground-based systems, monitoring of rolling stock using ground-based systems, infrastructure monitoring using on-board systems and monitoring of rolling stock using on-board systems [1]. Modern systems of monitoring and diagnostics of industrial and railway objects are reviewed in $[2,3]$.

The following methods are used to detect damages to wheel-sets in the railways of the world:

- ultrasound method;

- magnetic method;

- vibration-based method;

- acoustic emission method;

- strain-gauge method;

- fiber optic method.

Infrared camera, laser and high-speed camera-based methods are also used.

These methods are used both in ground-based and onboard rolling stock monitoring systems. The analysis of data acquisition technologies, examples of applications, advantages and disadvantages of such methods are given in [1].

In [4], the use of vibration diagnostic and acoustic-emission technologies for detecting damage to wheels and bearings of railway rolling stock was experimentally studied. For this purpose, laboratory and field tests were conducted, which enabled comparing the indicated technologies and concluding on expedience of their use. The following data acquisition technologies were investigated: estimation of peak to peak values, mobile RMS value, power spectrum, mobile excess, peak factor, cepstrum, and wavelet transform.

The results of laboratory experiments indicate that acoustic emission sensors and data acquisition technologies are advisable to use at low speeds to detect defects to axle bearings at an early stage of development. Accelerometers are mostly inef- 
fective for detecting defects to axle bearing in on-board and ground-based rolling stock monitoring systems, while their use for detecting wheel flats and weld-on deposits on the wheels by calculating values of the peak factor proved to be effective.

In general, the author of [4] concludes that most technologies that detected damage to wheels and axle bearings during laboratory experiments proved to be ineffective during field tests.

In [5], vertical acceleration of the axle box for detecting wheel flats on wheel-sets during movement of the car is also considered. The authors propose to use the empirical mode decomposition as a data acquisition technology, which is a method of adaptive signal analysis that does not require any defined basic function. Laboratory tests were carried out to confirm the effectiveness of this technology.

Mechanical vibrations of wheel-sets can serve as a source of diagnostic information for assessing the technical condition of the rail track. In [6], the vertical acceleration data of the axle boxes was acquired to assess and monitor the technical state of the switchover. An analysis of the dynamic properties of accelerometers and the use of fractional derivatives in the simulation of the operation of these sensors is given in [7, 8].

Unsolved aspects of the problem. The variety of cars and types of wheels, difficult installation and maintenance problems, strict requirements for the strength of the sensors together with the considerable costs of equipping the axle boxes limit the use of on-board monitoring systems. Multiple studies conducted in above-mentioned approaches were simulated and tested in laboratory conditions, while field studies were not given enough attention.

As a result, on-board monitoring of the technical condition of wheel-sets has had many complications that are still to be overcome.

Purpose. The purpose of this study is improving the maintenance technology for wheel-sets of passenger cars using the on-board monitoring system and acoustic monitoring method.

The following tasks were set to achieve the purpose:

- proposing an alternative approach to monitoring the technical condition of the wheels in motion of the car, reducing the number of sensors per car and improving their operating conditions;

- conducting a field study of the acoustic monitoring method;

- analyzing the obtained data, comparing them with the results of theoretical studies;

- using the study results for programming and configuring the wheel-sets acoustic monitoring device.

We have proposed an alternative approach to monitoring the technical condition of wheel-sets in motion of the car, which is based on recording elastic vibration of the wheel through the air by sensors installed on the frame of the car. This approach can be used to monitor the technical condition of rolling stock and railway infrastructure, including acoustic track monitoring.

When sound vibrations are used as a source of diagnostic information, certain features in comparison with the analysis of vibration or acoustic emission signals occur [4]. Simulation and laboratory studies of noise emission are complex and insufficiently effective, therefore, it was decided to study these processes in field conditions.

Description of the methodology of the study. The first stage of the experimental study of the acoustic monitoring method is recording sound implementations of acoustic signal sources in a wide range of frequencies. This requires:

- formulating requirements and choosing a measuring device;

- substantiating and choosing the arrangement scheme of the device relative to the train.

The document regulating the procedure for measuring railway noise emission is ISO 3095-2005 [9]. This internation- al standard defines the conditions for obtaining reproducible and comparative results of measurements of levels and spectra of noise emitted by all types of railway transport. In accordance with the standard for assessing the sound emission of the railway transport, the measuring equipment must meet the requirements for measuring instruments of accuracy class 1. Accordingly, the sound recorder should meet the following requirements:

a) operating frequency range of $31.5 \mathrm{~Hz}$ to $20 \mathrm{kHz}$;

b) uniform frequency response;

c) adjustable microphone sensitivity;

d) bit rate of the processor not less than 16 bits;

e) sampling rate not less than $48 \mathrm{kHz}$;

f) wind protection;

g) recording in solid-state memory, connecting to a PC.

The two-channel professional $\mathrm{H} 4 \mathrm{n}$ recorder Handy Recorder by ZOOM (Japan) meets all the above requirements.

To measure the railway noise emission, the measuring microphone should be located at standard positions at a distance of 3.5, 7.5, $25 \mathrm{~m}$ from the axis of the road 1.2, 1.6, $3.5 \mathrm{~m}$ above the surface of the top of the rail [9]. To record the noise of the running gear of passenger cars, in view of the above requirements, the measuring microphone is located $3.5 \mathrm{~m}$ from the axis of the road $1 \mathrm{~m}$ above the surface of the top of the rail (Fig. 1).

During the study, the following requirements regarding the measurement conditions were met:

- a circle with a radius of $50 \mathrm{~m}$ should be free of large sound reflecting objects (hills, bridges, houses);

- the area near the microphone should be free of objects that can disturb the free sound field;

- a windscreen deflector should be used; measurement is not carried out if a wind speed is more than $5 \mathrm{~m} / \mathrm{s}$.

The following external conditions are accepted:

- P65 rails, crushed stone ballast, concrete sleepers;

- average wind speed $4 \mathrm{~m} / \mathrm{s}$, average air temperature $34^{\circ} \mathrm{C}$, average atmospheric pressure $744 \mathrm{~mm} \mathrm{Hg}$.

Field studies were conducted with the following types of rolling stock:

- passenger cars (total number 204; range of speeds 18 to $80 \mathrm{~km} / \mathrm{h}$ );

- freight cars $(282 ; 5$ to $74 \mathrm{~km} / \mathrm{h})$;

- electric train cars $(38 ; 35$ to $60 \mathrm{~km} / \mathrm{h})$.

To increase the reliability of measurements, the record was made on two channels of the device, which allows preventing errors of one of the microphones.

Results. The technical condition of the wheel-sets most fully manifests itself in motion during interaction with rails. Short roughness of the rolling surface of the wheels causes impact loads that initiate oscillations of the unsprung parts of the car and can be detected by acoustic monitoring methods.

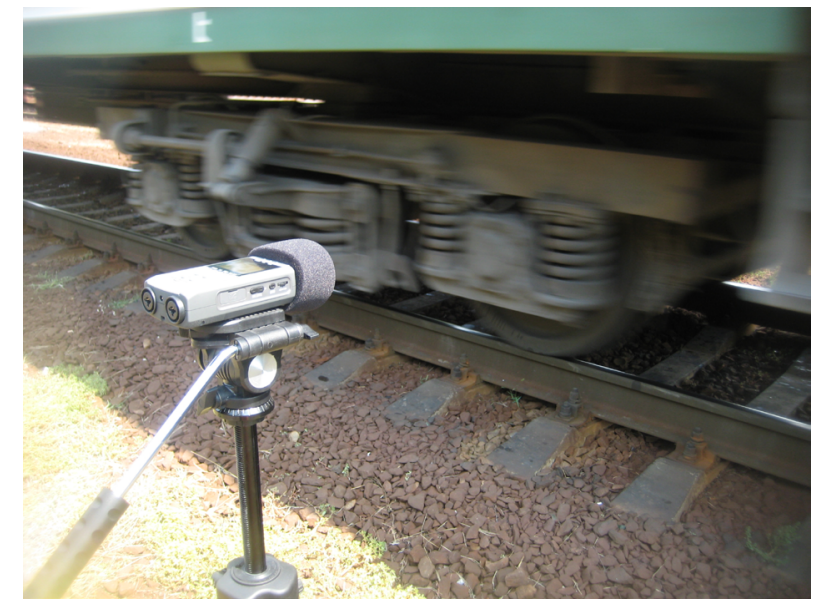

Fig. 1. Arrangement of the sound recorder relative to the train 
The rolling noise from wheels on the rails is caused by roughness of the rolling surfaces of the wheel and the rails. Most commonly, such roughness is regarded as stochastic. However, in the event of damage to the rolling surface of the wheels, the stochastic roughness becomes periodic. When such a wheel rolls, dynamic forces appear which lead to oscillation of wheel-sets and track elements. Oscillating surfaces emit sound waves that form a total sound pressure. The wheel disc is a dominant surface during noise emission.

During field measurements, the following main sources of noise emissions in motion of cars were focused on:

- rolling noise of wheels;

- impact interaction of the wheel and the rail;

- screech in curves;

- interaction of the brake block and the wheel;

- air release from the air brake control valves.

Since the spectral representation is the most informative method of analyzing sound vibrations, spectrograms of acoustic signals for each train are constructed after the preliminary processing and grouping of the results of measurements.

The purpose of analysis of spectrograms is determining the informative diagnostic signs of acoustic signals using which the latter can be divided into classes of images and configure the acoustic monitoring device for wheel-sets. The following phenomena and their characteristics are specific of the whole sample.

The rolling noise of passenger trains on average is a nonperiodic continuous signal in the frequency band from 150 to $1,000 \mathrm{~Hz}$ (Fig. 2). A segment of a high-frequency 17 to $20 \mathrm{kHz}$ signal duration of 2 seconds was also recorded during this implementation, corresponding to the short-term contact of the wheel flange with the inner edge of the rail. At low frequencies of 5 to $150 \mathrm{~Hz}$, non-periodic non-stationary noise formed by the wind barrier is recorded, which is 20 to $30 \mathrm{~dB}$ higher than the rolling noise.

Spectrogram in Fig. 3 illustrates the braking of rolling stock. Noise emission from friction of brake blocks occurs in the band 1 to $4 \mathrm{kHz}$, squeak at braking has one pronounced tone and shows itself at higher frequencies. Before the full stop of the train, the noise from friction of the brake blocks on the rolling surface of the wheel is expressed by a number of highfrequency 5 to $18 \mathrm{kHz}$ tone components.

The maximum spectral density of the energy of sound vibrations during air release from the air brake control valve PR No. 292 of the passenger car is observed in the frequency band of 7 to $15 \mathrm{kHz}$ (Fig. 4).

When a passenger train passes a short radius curve, the wheels rolling on the outer rail slip with noise emission (Fig. 5). The screech in the curve is single broadband pulses with a maximum spectral density in the range of 100 to $1000 \mathrm{~Hz}$. The recording is made at a speed of $10 \mathrm{~km} / \mathrm{h}$, at higher speed pulses merge into continuous noise.

In Fig. 6, a spectrogram of impact interaction of the wheel and the rail when six passenger cars pass a rail junction is con-

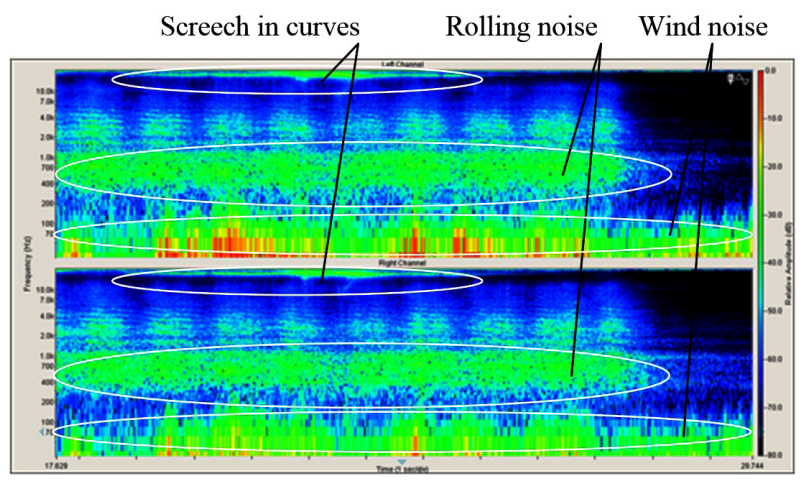

Fig. 2. Spectrogram of recorded sound of a moving passenger train

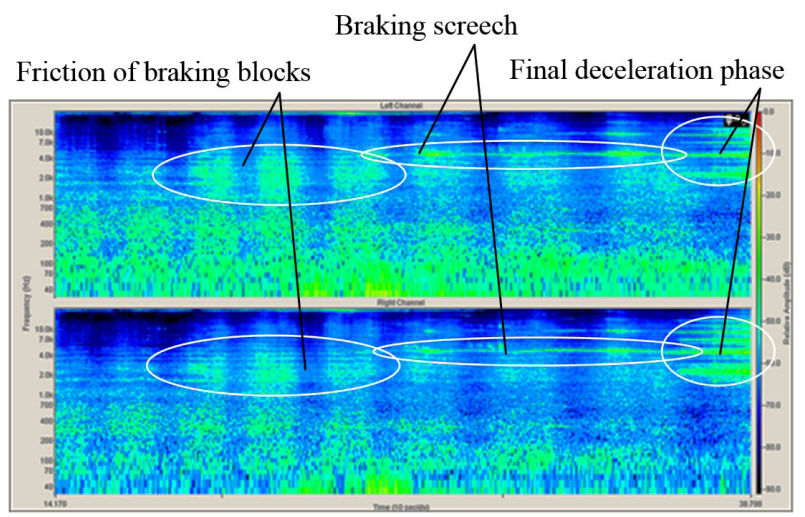

Fig. 3. Spectrogram of recorded braking sound of a passenger car

Air release from the air brake control valve PR No. 292

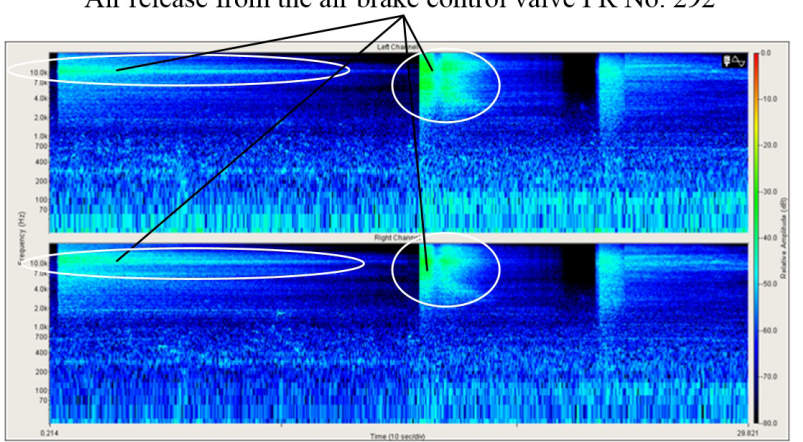

Fig. 4. Spectrogram of recorded air release sound from air brake control valve No. 292

Screech in a short radius curve

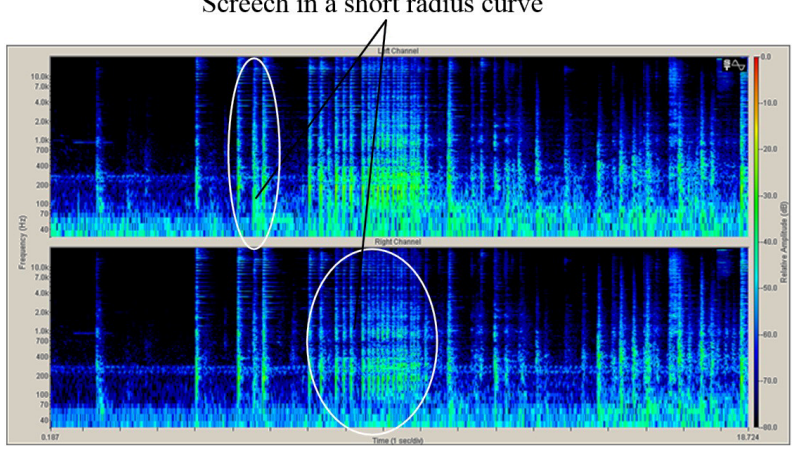

Fig. 5. Spectrogram of recorded screech in a short radius curve

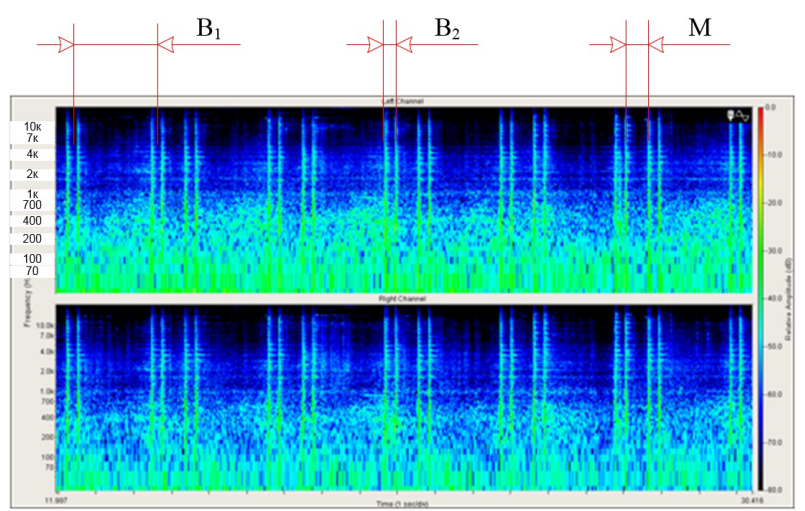

Fig. 6. Spectrogram of recorded sound of impact interaction of a wheel and a rail:

$B_{1}$ - bogie center distance; $B_{2}$ - wheel base; $M$ - distance between the extreme wheel-sets of connected cars 
structed. The sound implementation of the impact of the wheel on the rail is a broadband pulse lasting for 1 to $3 \mathrm{~ms}$, which is consistent with the theoretical studies [10].

In order to form an informative sample of sound implementations of the impact of the wheel on the rail, the experiment was conducted in the area where a train passes rail joints of different configurations. This approach is substantiated below.

To generalize the impact of the wheel on the rail when it passes the junction and when the wheel with a short roughness rolls, let us compare their forms in the time domain.

To compare the forms of acoustic signals, their envelopes were computed using the method based on the Hilbert transform. With such a transformation in the time domain, a connection is established between the actual and imaginary parts of a one-way signal, determined at $t \geq 0$ and equal to zero at $t<0$.

Let us represent an amplitude modulated signal as

$$
R(t)=\gamma(t) \cdot \eta(t),
$$

where $\gamma(t)$ and $\eta(t)$ are modulated and stationary random vibration components.

Modulated function is written as $\gamma(t)=1+m \cos \Omega t$, where $m$ is depth of modulation, $\Omega$ is circuit modulating frequency. Then signal $R(t)$ will be written

$$
R(t)=(1+m \cos \Omega t) \eta(t),
$$

where $\eta(t)$ is a high frequency stationary random vibration component with the effective bandwidth $\Delta \omega \gg \Omega$.

In this case, for the spectral analysis of the envelope, vibration components in the appropriate frequency band should be successively isolated from the signal to form their envelope and to perform a spectral analysis of the generated signal. Since the vibration signal envelope reflects its strength fluctuations over time, the selected part of the signal should not include components which have equal strength, but different nature of origin. Meeting this requirement is a complex practical task. When the frequency band of a signal is selected, which is isolated to form the envelope, the spectral density of the signal within this band should not change too dramatically (more than tenfold).

The envelope of the selected part of the signal can be formed by such an electronic device as a linear envelope detector and a low pass filter, and in case of the digital signal analysis - by an appropriate modification of the Hilbert transform.

It is established that the instantaneous strength of the output signal from the bandpass filter with effective width $\Delta \omega$, is $G_{0} \Delta \omega / 2 \pi$, where $G_{0}$ is the spectral density of the input signal of the filter. The average value of the output signal from the filter is zero. In the output signal from the linear detector at time $t$, the mean value is different from zero and is related to the value of the instantaneous strength of the input signal by expression

$$
y(t)=\gamma(t) \cdot \sqrt{G_{0} \Delta \omega} / 2 \pi .
$$

If slowly changing modulating function $\gamma(t)$ is determinate, i. e. contains a number of harmonic components

$$
\gamma(t)=1+\sum_{i=1}^{k} m_{i} \cos \left(\Omega_{i} t+\varphi_{i}\right),
$$

then in the input signal of the detector both a constant component $\sqrt{G_{0} \Delta \omega} / 2 \pi$, and harmonic components

$$
y_{i}(t)=\left(m_{i} / 2 \pi\right) \sqrt{G_{0} \Delta \omega} \cos \left(\Omega_{i} t+\varphi_{i}\right)
$$

appear.

Besides the above harmonic components of the modulating function, intense random components of a modulated random output signal are present in the linear detector. Their spectral density at low frequencies is

$$
G_{y}(\omega)=G_{0} / 4 \pi \text {. }
$$

During the spectral analysis of the low frequency part of the random vibration envelope with resolution $\Delta \omega_{A}$, every band of the analyzer frequencies will contain a component with RMS value

$$
Y_{\omega}=\sqrt{\frac{G_{y}(\omega) \Delta \omega_{A}}{2 \pi}}=\frac{1}{2 \pi} \sqrt{\frac{G_{0} \Delta \omega_{A}}{2}} .
$$

If a random output signal is modulated by a harmonic function with depth of modulation $\mathrm{m}$ and modulation frequency $\Omega$, then in the envelope spectrum at inverted frequency $\Omega$, RMS value of the signal will increase to the value

$$
Y_{\Omega}=Y_{\omega} \sqrt{1+q_{\Omega}^{2}}=Y_{\omega} \sqrt{1+m^{2} \frac{\Delta \omega}{\Delta \omega_{A}}},
$$

where $q_{\Omega}=Y_{\Omega} / \sqrt{2} Y_{\omega}=m \Delta \omega / \Delta \omega_{A}$ is signal/noise ratio in the frequency band $\Delta \omega_{A}$ of the analyzer with a central frequency $\Omega$.

From ratio $Y_{\Omega} / Y_{\omega}$ depth of modulation $m$ of random vibration at $\Omega(\%)$ is determined

$$
m=\sqrt{\left(\frac{Y_{\Omega}^{2}}{Y_{\omega}^{2}}-1\right) \frac{\Delta \omega_{A}}{\Delta \omega} .}
$$

In many practical cases, high-frequency random vibration is recorded by a piezoelectric vibration acceleration sensor not in linear, but in logarithmic units. Accordingly, the vibration envelope spectra are often determined in decibels, and the depth of random vibration modulation is determined by the difference between the levels of the harmonic component of the envelope spectrum and the average level of the random component in accordance with the expression

$$
m=\sqrt{\left(10^{\Delta L / 10}-1\right) \frac{\Delta \omega_{A}}{\Delta \omega}} .
$$

Expression (4) ceases to apply when intense harmonic components get into the frequency band of filter $\Delta \omega$ of the envelope detector.

To prevent errors in the analysis of random vibration envelope, before the measurement make sure that there is no intense harmonic or narrow-band random components in the frequency band of the envelope detector filter and there is no steep fall (rise) of the spectral density of the investigated random vibration.

The signal aligned by the Hilbert is determined by the expression

$$
\tilde{x}(t)=\frac{1}{\pi} \int_{-\infty}^{\infty} x(\tau) \frac{1}{t-\tau} d \tau,
$$

where $\tau$ is an independent variable; $x(t)$ is an actual signal.

In practice, instead of the integral (11), a direct and inverse Fourier transform (FFT-transform) is used, which allows calculating the result of the Hilbert transform in the time domain through the frequency domain

$$
\tilde{X}(f)=T F[\tilde{x}(t)]=X(f) \cdot H b(f),
$$

then

$$
\begin{array}{r}
\tilde{x}(t) \int_{-\infty}^{\infty} \tilde{X}(f) \exp (j 2 \pi f t) d f=\int_{-\infty}^{\infty} X(f) H b(f) \exp (j 2 \pi f t) d f ; \\
H b(f)=T F[1 / \pi t]=-j \cdot \operatorname{sgn}(f)= \begin{cases}-j, & f>0 \\
0, & f=0 . \\
j, & f<0\end{cases}
\end{array}
$$

Formula (13) defines transformation of signal by a system, the frequency transmitting characteristic of which is represented by function. Fourier image of function is 


$$
\tilde{X}(f)=-j \cdot \operatorname{sgn}(f) \cdot X(f) .
$$

If we have the following Hilbert transforms through the frequency domain

$$
\begin{gathered}
\tilde{x}(t)=-j \cdot \operatorname{sgn}(f) \cdot \frac{\left[\delta\left(f+f_{0}\right)+\delta\left(f-f_{0}\right)\right]}{2} ; \\
\tilde{X}(f)=-j \cdot \frac{\left[-\delta\left(f+f_{0}\right)+\delta\left(f-f_{0}\right)\right]}{2}= \\
=j \cdot \frac{\left[\delta\left(f+f_{0}\right)-\delta\left(f-f_{0}\right)\right]}{2} .
\end{gathered}
$$

With the inverse Fourier transform

$$
\tilde{x}(t)=T F^{-1}[\tilde{X}(f)]=\cos \left(2 \pi f_{0} t\right) .
$$

Expression (18) shows that the Hilbert transform shifts a phase for a quarter of a period for a single harmonic component of an acoustic signal.

Formation of a signal envelope in time is the most effective way of isolating a modulated component in cases where the spectral composition of the modulating and carrier components is different and is not superimposed in the frequency domain, i.e., the frequency domain of the carrier is much higher than the frequency domain of the modulating component. In vibration diagnosis, as a rule, two major cases are considered, where both components are periodic and when one of them is a stationary random process.

Signal envelope using the Hilbert transform is

$$
y(t)=\sqrt{x^{2}(t)+\tilde{x}^{2}(t)} .
$$

After acoustic signal envelopes were computed, smoothing functions were selected for them (Table 1).

According to Table 1, the acoustic signal envelopes of the impact of the wheel on the rail are approximated by logarithmic functions, and the order of the differences of functions within the group is proportional to the intergroup one. Since the differences between the noise emission during impact on the wheel rail with a wheel flat and passing rail joints are insignificant, as well as for the purpose of processing a more informative sample of experimental data, impacts of wheels passing rail joints were considered.

The most informative range of sound frequencies were calculated for reliable detection of such impulses in presence of interferences. The value of the peak factor in the frequency bands of the acoustic signal is selected as a criterion of informative importance (diagnostic sign).

For this purpose, each of the noise-emission records from the trains is divided into frequency bands of $0-70,70-100$, $100-200,200-400,400-1000 \mathrm{~Hz}, 1-2,2-4.4-7.7,10,10-$ $20 \mathrm{kHz}$ and in each band the peak factor is calculated. Figs. 7, 8 present the results of calculations in the form of graphs.

Dependence in Fig. 7 shows that the value of the peak factor of the noise recording noise practically does not depend on the selected frequency band and varies from 6 to 10 .

Dependences in Fig. 8, plotted for impact interaction of the wheel and the rail, demonstrate the growth of the peak factor in the range of medium and high frequencies.

\section{Table 1}

Functions smoothing acoustic signal envelopes

\begin{tabular}{|c|c|}
\hline Impact of the wheel flat & Impact on the rail joint \\
\hline$y_{1}(t)=45.8-10.1 \cdot \log _{10}(t)$ & $y_{1}^{\mathrm{I}}(t)=32.8-7.5 \cdot \log _{10}(t)$ \\
\hline$y_{2}(t)=57.7-13.5 \cdot \log _{10}(t)$ & $y_{2}^{\mathrm{I}}(t)=35.4-8.2 \cdot \log _{10}(t)$ \\
\hline
\end{tabular}

For a more precise identification of the frequency range and values of the peak factor from the impact interaction of the wheel and the rail, the data for all passenger cars of the sample were averaged, as shown in Fig. 9.

The dependence (Fig. 9) shows that the value of the peak factor remains constant at frequencies up to $1 \mathrm{kHz}$, because the wheel rolling noise on the rail and the wind noise that are not impulse processes dominate in this range. In the range of 1 to $20 \mathrm{kHz}$, the value of the peak factor increases continuously to 25 due to a decrease in the RMS value of the sound in this range and a more obvious manifestation of impulses from the impact of the wheel on the rail.

Since at frequencies of $7-15 \mathrm{kHz}$, air is released from the air brake control valve PR No. 292, and at 17 to $20 \mathrm{kHz}$, there is a squeak caused by the contact of the wheel flange and rail in the curve, the most informative to identify the impact of the wheel on the rail is the frequency range 2 to $5 \mathrm{kHz}$. Since this band has a high signal/noise ratio, a simpler defect detecting technique without complicated signal transformations can be used.

On the basis of the analysis of field acoustic measurements, a technical specification for the on-board unit for

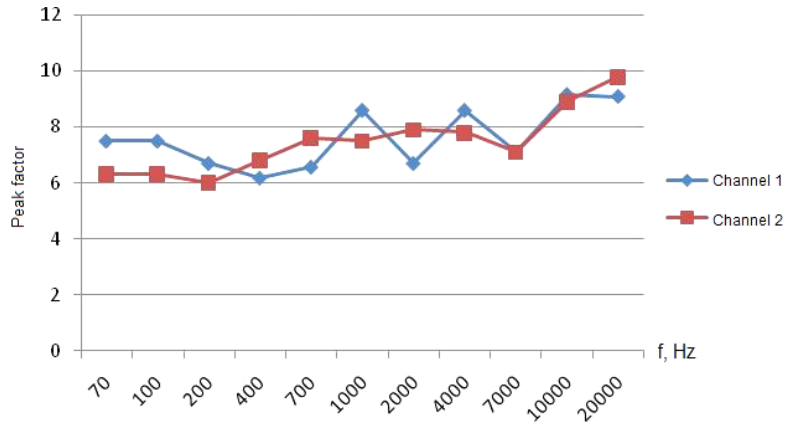

Fig. 7. Peak factor in the frequency bands of the acoustic signal of the rolling noise

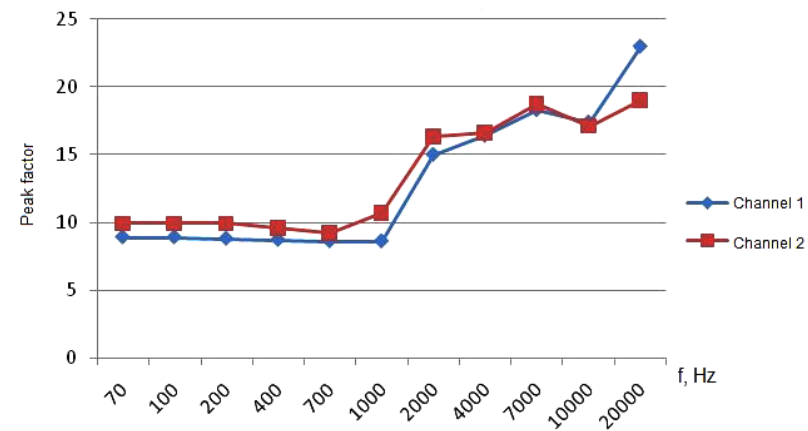

Fig. 8. Peak factor in the frequency bands of the acoustic signal from the wheel impact on the rail

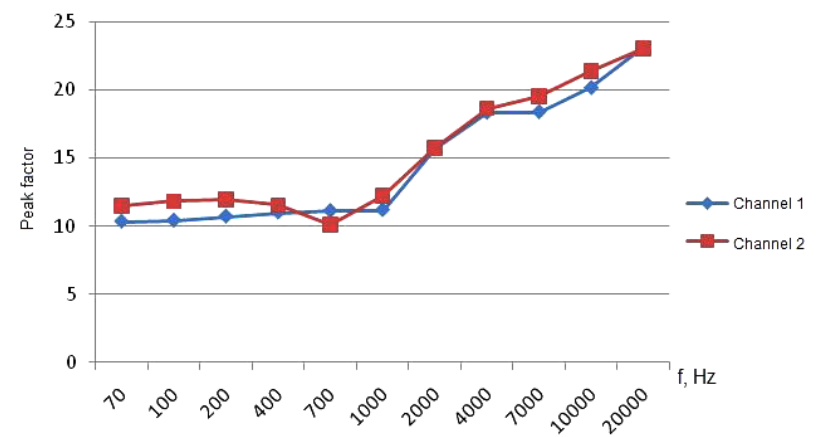

Fig. 9. Average values of the peak factor in the frequency bands of the acoustic signal from the impact of the wheel on the rail 


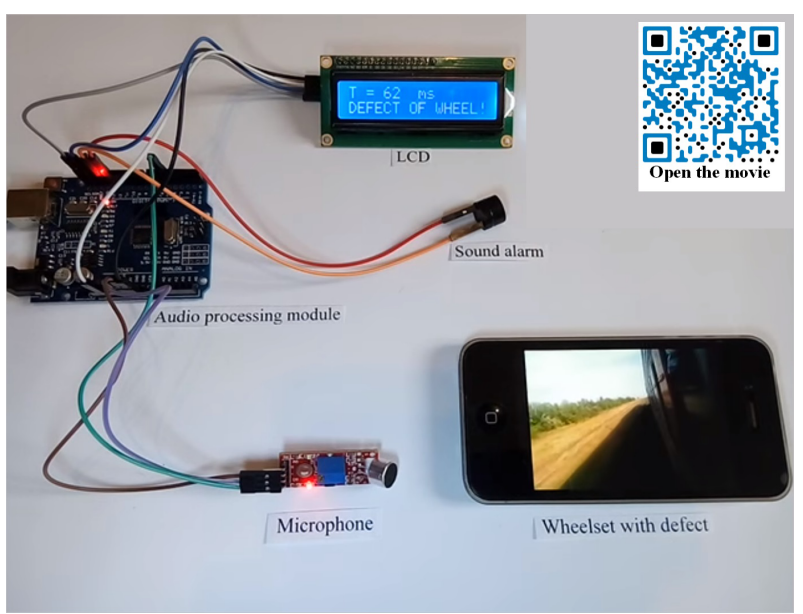

Fig. 10. Microcontroller-based acoustic monitoring device for wheel-sets of cars

monitoring the wheel-sets of passenger cars during the movement is formulated, on the basis of which a microcontrollerbased prototype sample of such a device was developed, configured and tested. The results of theoretical and experimental studies were used in programming during testing of the acoustic monitoring device. The final studies were conducted in the laboratory, using a smart phone with recorded movement sound of a car with a wheel flat on the wheel pair as a simulator of sound vibrations (Fig. 10). More information about the laboratory research process is available at the QR-code link.

This implementation of the acoustic monitoring method and device for wheel-sets of cars has considerable flexibility and allows refining the operation algorithm of the sound processing unit, quick modifying and easy configuring of the components of the circuit, which in general increases the reliability of the diagnosis.

Conclusions. In the article, an alternative approach to monitoring the technical condition of wheel-sets during the movement of the car was proposed, which allowed reducing the number of sensors per car and improving their operational conditions. Field studies of the acoustic monitoring method were conducted. Analysis of the obtained data showed consistency with the results of theoretical studies. Isolation of diagnostic signs from the broadband acoustic signal and calculation of the peak factor in the frequency bands allowed configuring the acoustic monitoring device for wheel-sets. The laboratory tests were conducted, the results of which showed the effectiveness of using the acoustic method for detecting damages of wheel-sets during movement of the car.

Further development of this topic may include operational tests of the acoustic monitoring method and device, refinement of the signal processing and equipment configuration algorithm, more detailed scientific substantiation of processes of noise generation and noise emission of cars in motion.

\section{Reference.}

1. Alemi Alireza, Francesco Corman, \& Gabriel Lodewijks (2017). Condition monitoring approaches for the detection of railway wheel defects. Proceedings of the Institution of Mechanical Engineers, Part F: Journal of Rail and Rapid Transit, 231(8), 961-981.

2. Lukasik, Z., Nowakowski, W., \& Wojciechowski, J. (2014). Wyposażenie laboratorium systemów sterowania i diagnostyki pojazdów szynowych w symulator pulpitu maszynisty. Czasopismo: Logistyka (journal ISSN: 1231-5478), Zeszyt, 6, 69176921.

3. Maj, M., Perzyński, T., \& Pietruszczak, D. (2018). Monitoring obiektów przemysłowych na przykładzie systemu kontroli dostępu bibinet. Autobusy: technika, eksploatacja, systemy transportowe. 19(6), 581-585.
4. Amini Arash, Mani Entezami, \& Mayorkinos Papaelias (2016). Onboard detection of railway axle bearing defects using envelope analysis of high frequency acoustic emission signals. Case Studies in Nondestructive Testing and Evaluation, 6, 8-16.

5. Li Yifan, Jianxin Liu, \& Yan Wang (2016). Railway wheel flat detection based on improved empirical mode decomposition. Shock and Vibration, 2016, 1-14.

6. Kaewunruen Sakdirat (2014). Monitoring structural deterioration of railway turnout systems via dynamic wheel/rail interaction. Case Studies in Nondestructive Testing and Evaluation, 1, 19-24.

7. Luft, M., Cioć, R., \& Pietruszczak, D. (2014). Analysis of selected dynamic properties of quasi-fractional-order measuring transducer used in transportation facilities. Archives of Transport System Telematics, 7(3), 17-21.

8. Pietruszczak, D., Luft, M., \& Lesiak, P. (2015). Some applications of fractional calculus in modelling of accelerometer and pressure transducer. Zeszyty Naukowe Wydziału Elektrotechniki i Automatyki Politechniki Gdańskiej, 47, 147-150.

9. ISO 3095:2005. Railway application-acoustics-measurement of noise emitted by railbound vehicles.

10. Martynov, I.E., Bondarenko, V.V., \& Skurikhin, D.I. (2014). Mathematical simulation of oscillation of a wheel pair as the basis of the acoustic monitoring method. East-European Journal of Advanced Technologies, 1(7), 22-28.

\section{Експериментальне дослідження методу та пристрою акустичного контролю колісних пар під час руху вагона}

\section{В. В. Бондаренко ${ }^{1}$, Д. І. Скуріхін ${ }^{1}$, Р. І. Візняк ${ }^{1}$, В. Г. Равлюк ${ }^{1}$, В. І. Скуріхін}

1 - Український державний університет залізничного транспорту, м. Харків, Україна, e-mail: skurikhin@i.ua 2 - Харківський національний університет міського господарства імені О. М. Бекетова, м. Харків, Україна

Мета. Удосконалення технології технічного обслуговування колісних пар пасажирських вагонів на основі бортової системи моніторингу та методу акустичного контролю.

Методика. Польові дослідження методу акустичного контролю проводилися відповідно до вимог діючих стандартів професійним звукозаписним приладом. Аналіз початкових даних проведено в ліцензійному програмному забезпеченні, побудовані обвідні акустичних сигналів за допомогою перетворення Гілберта, розраховані значення пік-фактору акустичного сигналу від взаємодії колеса та рейки в діапазонах частот.

Результати. Проведено аналіз методів виявлення пошкоджень колісних пар на залізницях світу й запропоновано альтернативний підхід до моніторингу технічного стану колісних пар під час руху вагона. Проведені польові дослідження методу акустичного контролю, обробка та аналіз отриманих даних, виявлені інформативні діагностичні ознаки. Результати дослідження застосовані для програмування й налаштування пристрою акустичного контролю колісних пар.

Наукова новизна. Уперше експериментально досліджені джерела шумовипромінення вагонів під час руху в експлуатації, проведена класифікація джерел шуму рухомого складу, виявлені й розраховані інформативні діагностичні ознаки сигналу для виявлення пошкоджень коліс на основі акустичного методу контролю.

Практична значимість. На основі експериментальних досліджень і подальших розрахунків розроблено та налаштовано макет пристрою акустичного контролю, що дозволило зменшити кількість датчиків на вагон і покра- 
щити умови їх роботи. Проведені лабораторні випробування розробленого пристрою.

Ключові слова: залізничний транспорт, вагони, колісні пари, моніторинг технічного стану, метод акустичного контролю, польові дослідження, спектрограма, пік-фактор

\section{Экспериментальное исследование метода и устройства акустического контроля колесных пар во время движения вагона}

\section{В. В. Бондаренко ${ }^{1}$, Д. И. Скурихин ${ }^{1}$, Р. И. Визняк ${ }^{1}$,} В. Г. Равлюк ${ }^{1}$ В. И. Скурихин ${ }^{2}$

$1-$ Украинский государственный университет железнодорожного транспорта, г. Харьков, Украина, e-mail: skurikhin@i.ua

2 - Харьковский национальный университет городского хозяйства имени А.Н. Бекетова, г. Харьков, Украина

Цель. Совершенствование технологии технического обслуживания колесных пар пассажирских вагонов на основе бортовой системы мониторинга и метода акустического контроля.

Методика. Полевые исследования метода акустического контроля проводились в соответствии с требованиями действующих стандартов профессиональным звукозаписывающим устройством. Анализ исходных данных проведен в лицензионном программном обеспечении, построены огибающие акустических сигналов с помощью преобразования Гилберта, рассчитаны значения пик-фактора акустического сигнала от взаимодействия колеса и рельса в диапазонах частот.

Результаты. Проведен анализ методов выявления повреждений колесных пар на железных дорогах мира и предложен альтернативный подход к мониторингу технического состояния колесных пар во время движения вагона. Проведены полевые исследования метода акустического контроля, обработка и анализ полученных данных, выявлены информативные диагностические признаки. Результаты исследования применены для программирования и настройки устройства акустического контроля колесных пар.

Научная новизна. Впервые экспериментально исследованы источники шумоизлучения вагонов во время движения в эксплуатации, проведена классификация источников шума подвижного состава, выявлены и рассчитаны информативные диагностические признаки сигнала для обнаружения повреждений колес на основе акустического метода контроля.

Практическая значимость. На основе экспериментальных исследований и последующих расчетов разработан и настроен макет устройства акустического контроля, что позволило уменьшить количество датчиков на вагон и улучшить условия их работы. Проведены лабораторные испытания разработанного устройства.

Ключевые слова: железнодорожный транспорт, вагоны, колесные пары, мониторинг технического состояния, метод акустического контроля, полевые исследования, спектрограмма, пик-фактор

Рекомендовано до публікаиії докт. техн. наук О. В. Устенком. Дата надходження рукопису 03.09.18. 